\title{
Sportslig språkforvirring
}

\author{
Begrepene tennisalbue, golfalbue og epikondylitt er misvisende. Vi foreslår heller å bruke betegnelsene \\ lateral og medial epikondyalgi.
}

Som ivrige tennisspillere hører vi ofte at begrepene tennisalbue og golfalbue brukes om smerter i muskulatur på henholdsvis lateral- og medialsiden av albuen. I faglitteraturen er plagene tradisjonelt blitt omtalt som lateral og medial epikondylitt. Nyere studier har vist at aktiv inflammasjon sjelden er involvert i tilstandene, og derfor er lateral og medial epikondyalgi bedre betegnelser $(1-4)$.

Plager i albuen har lenge vært et kjent problem blant tennis- og golfspillere. På midten av 1800-tallet ble moderne tennis populært blant Storbritannias aristokrater, og i 1882 omtalte den britiske kirurgen Henry Morris (1844-1926) the lawn tennis arm i en Lancet-artikkel $(5,6)$. En studie av tennismosjonister i 1970-årene viste at $40 \%$ hadde opplevd albuesmerter i løpet av livet, og prevalensen ble beregnet til $14 \%$ (7).Til sammenlikning har en nyere studie vist at prevalensen av tennisalbue i normalbefolkningen er rundt $1 \%(8)$. Eldre epidemiologiske studier av golfspillere har også vist at insidensen av medial epikondyalgi er høyere blant golfspillere enn i befolkningen generelt $(8,9)$.

Vår erfaring er likevel at tennisalbue er sjeldnere blant tennisspillere i dag. Selv om nye epidemiologiske studier av albueplager hos tennisspillere ikke er tilgjengelige, er det vitenskapelige holdepunkter for å hevde at problemet er synkende $(10,11)$. For det første har racket-teknologien endret seg radikalt fra 1980-årene til 2000-årene. Lettere racketer kan i seg selv gi mindre belastning på underarmen. Dessuten har moderne racketer ført til store endringer i teknikk og spillestiler. Blant annet er enhåndsbackhand nesten ikke i bruk blant yngre norske spillere, og biomekaniske studier har vist at tohåndsbackand gir mindre belastning på laterale albuemuskler (10).

På den annen side er plager på den mediale siden av epikondylen et økende problem hos moderne tennisspillere. En fersk studie av tennisspillende tenåringer viste medial epikondylær fragmentering hos $37 \%$, og $22 \%$ var plaget med mediale albuesmerter (12). Golfalbue ser altså ut til å være den nye tennisalbuen. Trolig kan denne økningen forklares med endret teknikk på forehand som i større grad belaster den mediale albuemuskulaturen.
I amerikanske og engelske studier hevdes det at færre enn $10 \%$ av pasientene med tennisalbue spiller tennis $(5,7,11)$. Tallene er basert på eldre data, og vi tror dermed at andelen er enda lavere i dag. I Norge er dessuten tennis mindre utbredt enn i de engelsktalende landene. Hos de aller fleste pasienter vil derfor laterale albueplager ha andre årsaker enn tennis.

Vi mener at begrepene tennisalbue og golfalbue er forvirrende og utdaterte. Skadene bør heller omtales med ord som beskriver patogenesen. Det betyr også at epikondylitt er et upresist begrep, og vi oppfordrer derfor klinikerne til å omtale skadene som laterale og mediale epikondyalgier.

\section{Frederik Emil Juul}

redaktor.aesculap@gmail.com

Universitetet i Oslo

\section{Jens-Øyvind Samuelsen}

Sykehuset Telemark

Mats Julius Stensrud

Universitetet i Oslo

Frederik Emil Juul (f. 1989) er medisinstudent og redaktør i Æsculap.

Jens-Øyvind Samuelsen (f. 1989) er turnuslege.

Mats Julius Stensrud (f. 1989) er medisinstudent og dr.philos.

\section{Litteratur}

1. Waugh EJ. Lateral epicondylalgia or epicondylitis: what's in a name? See comment in PubMed Commons belowJ Orthop Sports Phys Ther 2005; 35: mons 2 .

2. Maffulli N, Khan KM, Puddu G. Overuse tendon conditions: time to change a confusing terminology. Arthroscopy 1998; 14: 840-3.

3. Kraushaar BS, Nirschl RP. Tendinosis of the elbow (tennis elbow). Clinical features and findings of histological, immunohistochemical, and electron microscopy studies. J Bone Joint Surg Am 1999; 81: 259-78

4. Taylor SA, Hannafin JA. Evaluation and management of elbow tendinopathy. Sports Health 2012; 4: 384-93.

5. Flatt AE. Tennis elbow. Proc (Bayl Univ Med Cent) 2008; 21: 400-2.

6. Morris H. The rider's sprain. Lancet 1882; 2: $133-4$.

7. Gruchow HW, Pelletier D. An epidemiologic study of tennis elbow. Incidence, recurrence, and effectiveness of prevention strategies. Am J Sports Med 1979; 7: 234-8.

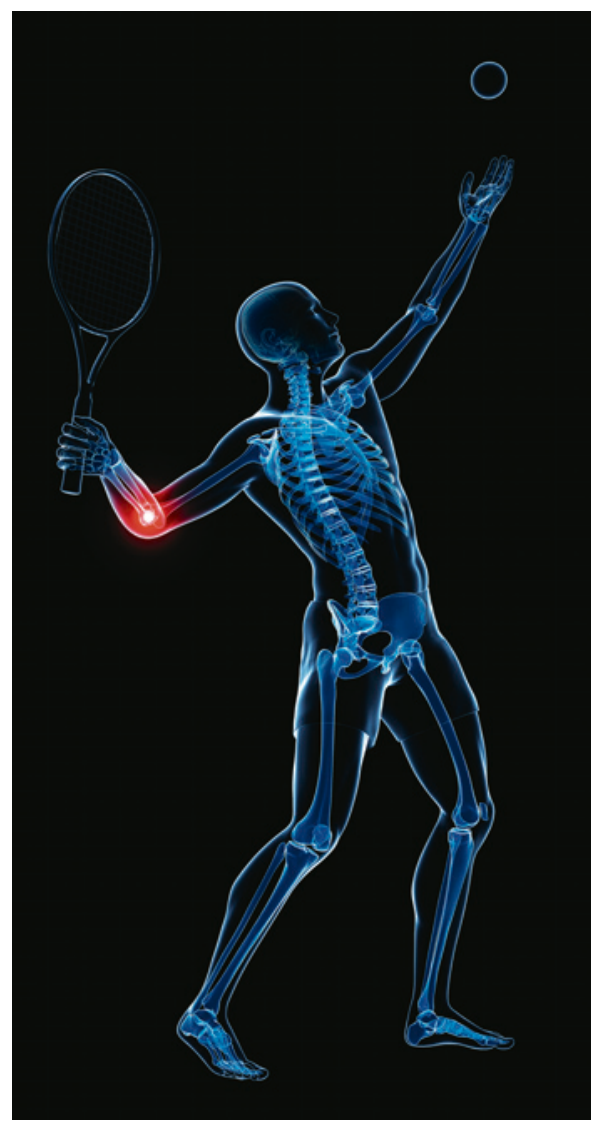

Illustrasjonsfoto: Science Photo Library

8. Shiri R, Viikari-Juntura E, Varonen $\mathrm{H}$ et al. Prevalence and determinants of lateral and medial epicondylitis: a population study. Am J Epidemiol 2006; 164: 1065-74.

9. Batt ME. A survey of golf injuries in amateur golfers. Br J Sports Med 1992; 26: 63-5.

10. Giangarra CE, Conroy B, Jobe FW et al. Electromyographic and cinematographic analysis of elbow function in tennis players using single-and double-handed backhand strokes. Am J Sports Med 1993; 21: 394-9.

11. De Smedt T, de Jong A, Van Leemput W et al. Lateral epicondylitis in tennis: update on aetiology, biomechanics and treatment. Br J Sports Med 2007; 41: 816-9.

12. Harada M, Takahara M, Maruyama M et al. Characteristics and prognosis of medial epicondylar fragmentation of the humerus in male junior tennis players. J Shoulder Elbow Surg 2014; 23: 1514-20.

Mottatt 15.5. 2015, første revisjon innsendt 24.5. 2015, godkjent 27.5. 2015. Redaktør: Erlend Hem. 